\title{
A Perspective on Social-Ecological System Framework And New Institutional Economics Theories in Explaining Public Open Spaces (Pos) Governance And Quality Issues
}

\author{
Gabriel Hoh Teck Ling ${ }^{1}$ \\ ${ }^{1}$ UTM-Low Carbon Asia Research Centre, Urban and Regional Planning, Faculty of Built \\ Environment and Surveying, Universiti Teknologi Malaysia, 81310, Skudai, Johor Bahru, Johor \\ Darul Takzim, Malaysia.
}

gabriel.ling@utm.my ${ }^{l *}$

Received: 18 June 2018 Final Version Received: 28 August 2019

\begin{abstract}
There has been relatively little attention paid to the implications of property-rights structures on urban and neighbourhood commons, particularly in respect to government/state-owned public open space (POS) governance, its management and its quality. By establishing interconnections of the property-rights structure with POS governance and its quality externalities, the theory of new institutional economics, the social-ecological system framework, as well as the social dilemma theory and the commons and opportunism concepts were employed and reviewed, to synthesise a conceptual framework which can help illuminate and explain the complex nexus of an institutional-social-POS system. Findings suggested that adversarial institutional design and arrangement (e.g., maladaptive property regime, incomplete rights, and attenuated rights) and change of the property-rights system, coupled with highly positive transaction cost distributions, contribute to inefficient POS governance and management, which consequently results in a suboptimal quality and sustainability of POS. This synthesis provides policy and management insights by making public officials aware of the importance of the institutional-social-ecological system, and by making them consider a re-engineering of the POS ownership regime and its management rights via an adaptive property-rights structure assessment and re-allocation.
\end{abstract}

Keywords: Property-Rights System, Public Open Space, Opportunism, Governance, Commons Dilemmas

\section{INTRODUCTION}

There is growing debate and concern on how to design more environmentally sustainable cities. Seeing the importance of provision (quantity) and quality dimensions of public open spaces (POS) in urban planning and built environments (Malek et al., 2018) that essentially contribute to the urban quality of life, a plethora of studies with respect to protection and management of public open spaces (POS) have been attempted. These studies cover the perceptional effects, the attitude and socioeconomic position of stakeholders towards POS protection, spatial, landscape, and architectural POS design planning models (e.g., location, size, and shape of POS) (see Malek et al., 2018), as well as the "traditional" planning system and policies on public open spaces (e.g., prescriptive land use zoning and density). Nevertheless, the governance plights of government-owned urban and neighbourhood POS, concerning overexploitation (e.g., vandalism, illegal misuse and conversion of land use/POS, congestion and squatters settlement encroachment), mismanagement and underinvestment, are burgeoning. These subsequently result in POS negative externalities and market failures, thereby adversely affecting liveability and sustainability of the society, due to reduced safety and security, pollution, temperature rise, climate change, social disintegration and other health issues (Colding et al., 2013; Ling et al., 2016; see also Soo et al., 2018). For instance, particularly for developing countries, the importance and protection of public open spaces (POS) in terms of their ecosystem service values, is often poorly integrated into urban planning and development policies. Such disintergration may pose detrimental effects to the wellbeing of 
the poor, as they do not have spacious places and gardens to use compared to the rich, who have the ability to engage better and more luxurious services via payments (membership fees) (Sangmoo, 2015). Inadequate POS protection and governance issues can be affirmed by many scholars. The POS quality issues which have been undermanaged and underinvested by local governments are found to be mostly due to their own incapabilities, e.g., limited financial and workforce resources and giving low priority to maintenance, which consequently demands an institutional change (Webster and Lai, 2003; Webster, 2007). The problems and social costs of the state/government-owned Tieboutianmodelled POS (Tiebout, 1956) posed are associated with governance (institutional), consumption and management aspects, rather than the sole spatial and architectural designbased dimension.

Therefore, the groundbreaking social-ecological system (SES) based new institutional economics (NIE) property-rights, and the transaction costs analytic framework/approach are employed to illuminate the urban-neighbourhood commons (POS) tragedy (see Lai et al., 2015 and Ling et al., 2018 on the need of urban and environmental planning with property-rights in mind). Particularly, analysing the implications of institutions on the human-environment interaction (consumption and management) and its outcome (quality and sustainability) is emphasised (see Lai, 2014). Such institutional dimensions, compared with traditional commons/resources (e.g., fisheries and irrigation), have been relatively underresearched, notably in the urban neighbourhood POS governance context (see Brown, 2015; Ling et al., 2016; Foster and Loine, 2016; Ling et al., 2018; Ling and Leng, 2018). Moreover, this institutional gap (factor) is fit to be analysed within the often-neglected environmental urban commons (POS) dilemmas (Khachatryan et al., 2013). This study is significant as it contributes to the existing knowledge pool and provides a practical implication on insights gained, whereby policy-makers (e.g., planners and urban economists) may understand better, from the institutional position, the status quo of stateowned POS governance and its quality outcomes.

\section{LITERATURE REVIEW}

\subsection{State-owned public open spaces (POS) as common pool resources (CPRs)}

Local governments provide many types of public goods (Tiebout, 1956). One of them is green public open spaces, which are held as a state (public) property, and are governed by the different institutions, laws and policies (Hanna et al., 1996). In the context of land-use and spatial planning, Ling et al., (2014) argue that open space is not a straightforward concept as it is subject to a range of definitions, functions and characteristics. These include public places and parks, community neighbourhood gardens, recreational spaces, outdoor public assembly spaces, natural landscapes, playgrounds, contiguous spaces between buildings, and urban green spaces.

In light of the publicness and unexclusiveness of open spaces (see Webster, 2002 and Ling et al., 2019 on the differences between public realm and public domain), and through the perspective of the commons theory, such public domain space (POS) is considered as a common/shared resource (commons), more accurately, an urban neighbourhood commons/CPRs (Hess, 2008; Colding et al., 2013). The definition and distinction of POS in terms of its terminology and features is indispensable because various property theorists and commons theorists have posed ambiguity and misconception. According to Ciriacy-Wantrup and Bishop (1975), commons resources can be deemed as a resource domain/ system, while common-property resources are generally viewed as a type of property-right regime that belongs to one specific group. Tersely, a multifaceted commons is a general term that refers to a shared resource system, in which individuals have equal rights of access and use. However, commons should not inevitably be entailed as an open and unrestricted access space, in which case such an argument is technically contrary to Hardin's (1968) - Tragedy of the Commons - who fallaciously ideated and considered commons as a propertyright regime - as an unowned, ungoverned and open-access grazing land. From the institutional and economic standpoint (see typology of goods), espousing Ostrom's (1990) assertion on the types of economic goods in this paper, CPRsbased POS must possess two properties: (i) nonexclusionary and (ii) subtractable/rivalrous, and such commons (POS) can exist in any resource or property regime. Hence, we may have to acknowledge that POS with CPR attributes have a difficulty or require high cost (whether institutionally or physically) in excluding and prohibiting the access of others to the resources, and every single access and use of the resource by an individual can reduce the opportunity and enjoyment for other users. 


\subsection{Application of social-ecological system (SES) framework and new institutional economics (NIE) for state-owned POS governance}

Ostrom (2009) proposes the SES diagnostic framework as a relevant and useful heuristic for understanding and examining the complex behavioural interactions and sustainability outcomes of human-environment (POS). Instead of adopting institution-free neoclassical economics and less-rigour old or institutional economic theories, the multidisciplinary Coasian NIE dimensions (Coase, 1960) covering theories and concepts of commons, opportunism, social dilemma/ game theory and collective action, are incorporated into the SES framework for a more realistic and robust analysis at explaining the social-ecological interactional behaviour (see Kherallah and Kirsten, 2002; Chen and Webster, 2012), especially in understanding the implications of institutions, property-rights, transaction costs, as well as their interrelationships on the social-ecological outcome. Within a complex, multilevel SES, it comprises common resources (POS), resource units (POS facilities and amenities conditions and functionality, landscape and cleanliness of surroundings), actors (residents, land officers, local authority, and managers), and governance systems/institutions (organisations and laws governing and regulating the management and consumption rights of POS). These respective distinct components and entities eventually interact and account for POS quality and sustainability outcomes.

\subsection{Institutions}

Following North's (1990) viewpoint, institutions are deemed as the rules of the game in society: the humanly constructed constraints that coordinate and influence human interaction. They are composed of formal (de jure) constraints (rules, laws, constitutions, regulations or guidelines, government policies), and informal (de facto) constraints (conventions, customs, practice) (Musole, 2009). These macro-level institutions (institutional environment) thus expand the institutional effects to the micro-level institutional arrangement, consisting of property-rights systems and transaction costs (Williamson, 2002) that emphasise the governance of managing transactions/interactions concerning the social-ecological system.

\subsection{Transaction cost economic}

There are numerous definitions and interpretations of transaction costs adopted by scholars including institutionalists, urbanists and economists (see North, 1990; Adhikari, 2001; and Webster and Lai, 2003) that fundamentally encompass market and non-market transaction costs, namely, costs of organising, managing, monitoring, supervising, legal fees, cooperation, information searching, predicting and imposing contractual relations, and cost of lobbying and queuing, respectively (see Eggertsson, 1990; North, 1990). Thus, it is relevant and appropriate to analyse the system and distribution of transaction costs to evaluate the efficiency and performance of an existing institutional structure. As Libecap (1991) and Musole (2009) maintain, incurring lower (negative/less positive) transaction costs is necessary for, and beneficial to, an SES, particularly concerning the enforcement of management. For instance, lower transaction costs promote more transactions and exchanges; enable and render property-rights system delineation and its enforcement/implementation; and enhance the production. Nevertheless, it is worth to be noted that the mere presence of high (positive) transaction costs does not always connote inefficiency that may adversely inhibit the above transactions, production and enforcement. Transaction costs are not necessary to be addressed and measured in a quantifiable monetary term (using an objectivist approach), instead, they can also be conveyed in the qualitative proxies (via an institutional/subjectivist approach), which include burden, efforts and time, e.g., uncertainty, social/commons dilemmas, and opportunism. Thus, for this paper's purpose, the latter seems more relevant and is adopted in conceptualising the institutional-social-POS system.

\subsection{Property-rights structure}

It is crucial to identify two key components within a property-rights structure/system, namely, property-rights regimes and propertyrights that the latter consists of economic rights bundle and legality of rights (see Buck, 1998; Heltberg, 2002). Similar to the description of the institutions above, legal/ de jure rights are rights assigned by governmental authorities and are sanctioned by laws. These formal rights and recognition are essential to protect and support the economic rights; the former ensures the latter is not being challenged. Economic rights are the ability of individuals to use their rights and interest over an asset or resource. According to Schlager and Ostrom (1992), economic rights 
are considered as a bundle of sticks, where each stick is comprised of a claim that provides individuals with a stream of benefits (e.g., use, exclusion, alienation, and management) and their respective positions (e.g., claimants have management, access and use rights). Exchanging of divisible economic property-rights, via property development (e.g., land subdivision) and dealings (alienation - transfer of rights) among individuals makes up a contractual agreement (Ling et al., 2016). It is essential to find out what exactly determines the economic rights bundle above, apart from the legal and self-enforced institutions. Buck (1998) and Hanna et al., (1996) both assert that property (bundle) rights are characterised and specified/assigned by property-rights regimes (ownership), and vice versa. There are four types

Table 1 - Four Types of Property-Rights Regimes 2007).

\begin{tabular}{|l|l|l|l|l|}
\hline \multicolumn{1}{|c|}{ Regimes } & \multicolumn{1}{|c|}{ Ownership } & \multicolumn{1}{c|}{ Owner rights } & \multicolumn{1}{c|}{ Owner duties } & \multicolumn{1}{c|}{ Access } \\
\hline Private property (res privatae) & Individual & $\begin{array}{l}\text { Social acceptable } \\
\text { and access control }\end{array}$ & $\begin{array}{l}\text { Avoid socially unacceptable } \\
\text { uses }\end{array}$ & Closed \\
\hline $\begin{array}{l}\text { Common property (public closed } \\
\text { access) (res communes) }\end{array}$ & Collective & $\begin{array}{l}\text { Exclusion of non- } \\
\text { members }\end{array}$ & $\begin{array}{l}\text { Maintenance- restrict the } \\
\text { rate of use }\end{array}$ & Group members only \\
\hline State property (res publica) & Government & Determine rules & Maintain social objective & All \\
\hline $\begin{array}{l}\text { Open-access resource (public } \\
\text { open access) (res nullius) }\end{array}$ & None & None & None & All \\
\hline
\end{tabular}

Source: Adapted from Hanna et al., (1996)

Apart from the economic performance, a plethora of literature also advocates the significant roles and implications of propertyrights institutions and transaction costs on the human-environment system (Ostrom, 1990; Webster, 2007). Such an institutional-socialecological relationship is true because the effects of property-rights on urban commons have also been discovered (Boydell et al., 2014; see Ling et al., 2016 for statistical association between the property-rights system and POS quality). Grafton (2000) argued that property-rights play a central role in understanding and explaining the issues associated with the overexploitation of the environment as they hinge upon market behaviour. Using Demsetz's (1967) theory of externalities internalisation via institutions, it is understood that different arrangements of property rights drive the stakeholders' management and consumption behaviour to respective incentives and costs distribution systems, resulting in different outcomes in terms of the allocation and sustainability of resources. of property-rights regimes (Heltberg, 2002) as shown in Table 1 below, although, in reality, these regimes are often overlapping. Each property regime design, associated with its strengths and weaknesses, leads to different resource governance implications regarding types of economic goods and quality outcome (see Ostrom, 2002). For instance, to curb market failures and negative externalities of POS in other regimes, such public domain CPR (playground and urban parks) are formally and commonly held as a state property, because it is regarded as the only means to protect and sustain its quality (Lee and Webster, 2006; Webster,

For instance, maladaptively designed institutions (property-rights system) and poorly governed land use and spatial planning policies, which render high perverse incentives and high transaction (enforcement) costs may ensue in undesirable market-ecological consequences (Musole, 2009). Similarly, in the rights assignation (pre-enforcement) stage, transaction cost distribution also defines the property-rights structure. When transaction costs are high, defining property rights may seem impossible. Consequently, such resource rights are not clear and are hence left unassigned (i.e., open-access resource), thereby negatively affecting marketecological behaviour and performance. There are interrelationships established between propertyrights, distribution of (perverse) incentives and transaction costs, and market-commons outcomes. A graphical framework (Figure 1) is constructed as a theoretical underpinning to succinctly showcase the previous review on the institutional (property-rights and transaction costs)-social-POS interaction. 


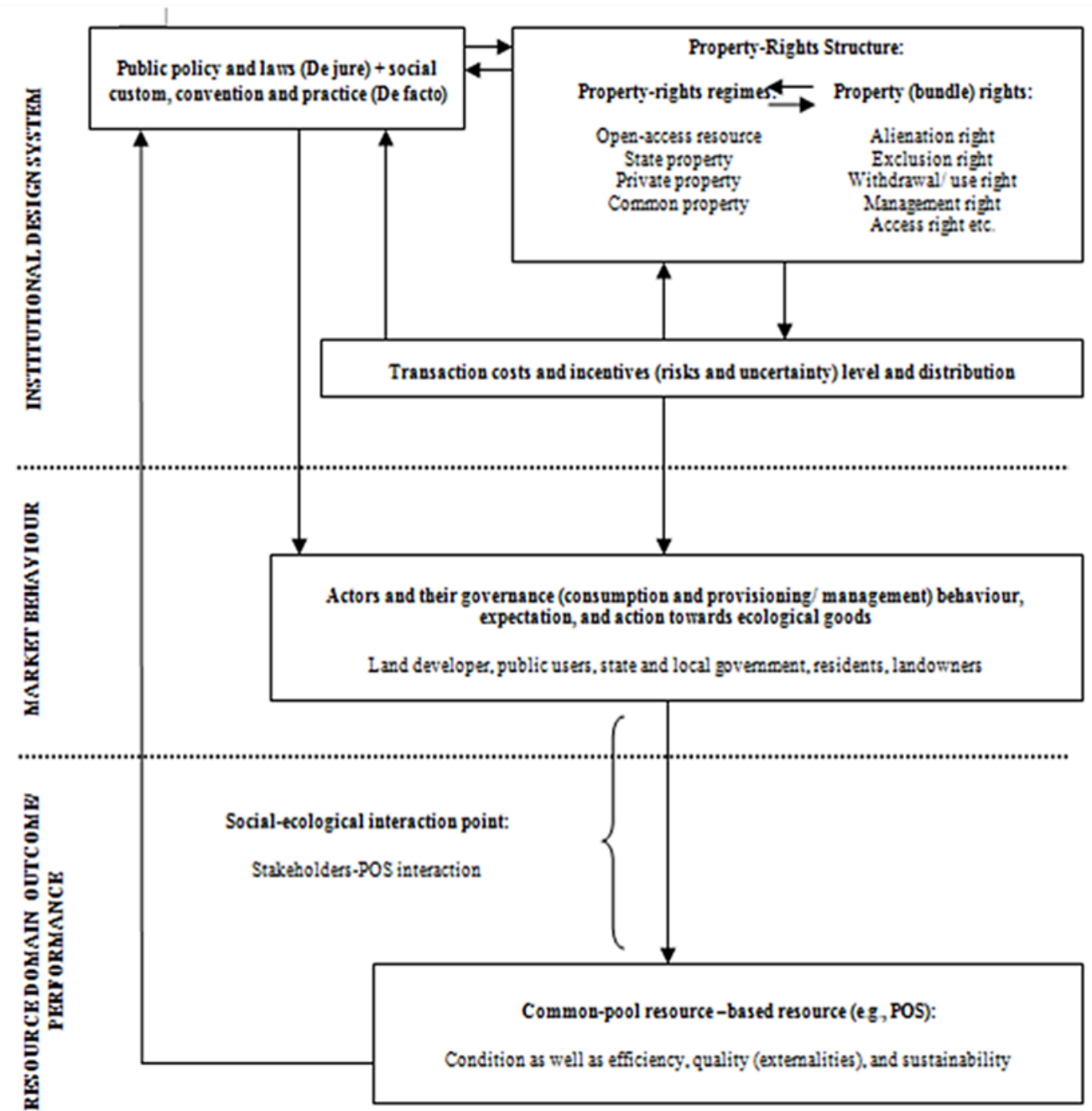

Figure 1- Interaction Between Institutional Design Structure, Stakeholders' Behaviour and Pos Outcome

Source: Adapted From Buitelaar And Needham, (2007); Gerber Et Al., (2009)

\section{SES-NIE CONCEPTUAL FRAMEWORK}

The above theoretical framework merely provides the overview and background, definitions, concepts and implications of the NIE elements covered in the institutional-humanenvironment analysis. This section presents a further review and analysis of the specific types and effects of institutional failures (issues of inefficiency in property-rights structure) that influence social-POS behavioural interactions and quality outcomes. By embedding other aforementioned theories and concepts of NIE into an SES, namely opportunism and social/commons dilemmas, it specifically addresses the following questions: (i) What forms of institutional issues and change are typically found in an institution; and (ii) Why and how these institutional failures trigger the opportunistic behaviour of actors and lead to inefficient governance (management and consumption) and suboptimal quality outcome of POS.

\subsection{Concepts of self-interest and opportunistic behaviour}

As institutions and market behaviour are rudimentarily associated, the issue of human behaviour (whether one acts self-interestedly) is underlined, particularly on the social-ecological (POS) decision making. Self-interest entails that individuals are always behaving selfishly by maximising their advantages (utility). There are two kinds of self-interests: defective self-interest (Pigou, 1932) and enlightened self-interest (see Adam Smith's 1776 invisible hand- positive externalities), of which the former is more focused on in this paper. Moreover, self-interest based opportunism offers a complete 
understanding in terms of social-ecological behaviour (see Williamson, 1975).

Williamson (1975) argues that in opportunism/opportunistic behaviour, individuals attempt to pursue their best interests while trying to break the rules/ contract. In his words, opportunism is "...to include self-interest seeking with guile". Guile here means rules and promise breaking that cover withholding or distorting information. Individuals cannot always be assumed to keep their promises in fulfilling their duties/rights (asymmetric commitment), although specific and clear terms and conditions have been consented in the exante. They may act deceptively after the contract (ex-post opportunism), e.g., involving oneself in moral hazards, shirking and free-riding, and overexploitation (see social dilemmas). Opportunism plays a primary role in transaction cost economics, particularly in this institutionalsocial-POS context. Nevertheless, not all agents will constantly behave opportunistically; instead, this instrumental concept is used to help analyse an individual's behaviour that may subsequently provide more accurate socialecological decision making. In short, when the institutional system is deemed unfit, market failures will be externalised; transaction costs and opportunism risk will become higher, which would lead to detrimental impacts on the efficiency of ecological distribution and its outcome.

\subsection{Commons dilemmas and negative externalities in urban and neighbourhood POS}

The above concepts of self-interest and opportunism are part of, and associated with, social dilemmas. The social dilemma is a reciprocal decision-making situation; here there is a difference between an individual's motive to maximise personal (self-interested) interests (convenience and enjoyment/utility) and his motive to maximise collective interests (Rapoport, 1998). The predisposition to maximise one's interest and gain is viewed as a defecting choice (dominant and prevalent strategy), while a desire to maximise the gain of the collective interest is regarded as a cooperative choice. Individuals always receive a higher return, at least in the short run, when they act opportunistically by making a defecting choice. This phenomenon can be further explicated in the game theory/prisoner's dilemma analogy. Regardless of the two basic categories of social dilemmas: public goods (giving/managing dilemma) and resource (taking/appropriating) dilemmas, they are altogether deemed CPR/commons dilemmas, as both dimensions of contribution (management) and consumption are concerned and relevant in the context of POS (see Ling et al., 2019).

In the context of POS, the following are the possible commons dilemmas faced:

(a) Shirking (avoiding the assigned duties, e.g., no development, mismanagement, underinvestment and less monitoring, or paying tax);

(b) Free-riding (individuals, e.g., squatters and outsiders who benefit from the services without paying any or equivalent tax and fees);

(c) Moral hazard (individuals are disincentivised to guard against or manage a risk when other agents protect it);

(d) Overexploitation (maximising the gain via use rights, e.g., POS misuse or illegal conversion of land) (see Hardinian Tragedy of the Commons, 1968). As a result of ambiguous and illdefined property rights, the Hardinian tragedy is a phenomenon where different self-interested individuals are granted with unrestricted consumption and access rights (freedom) to the given open-access resource (pasture) without any cost-effective mechanism to monitor, manage and regulate others' uses; therefore, the rivalrous CPRbased resource is vulnerable to over usage, which results in resource degradation and depletion;

(e) Disuse (authorities abandon or discontinue the use of resources); and

(f) Exclusion of resources for a private purpose that compromises the collective welfare.

The above POS dilemmas will be aggravated if more opportunistic behaviour is posed and the number of users (competition) escalate; they may lead to other dilemmas, and more negative externalities will be ensued (e.g., vandalism, poor landscaping and cleanliness issues, paper park, misuse or illegal conversion of POS uses) (McCarter et al., 2014). This phenomenon can be exemplified in Wilson and Kelling's (1982) broken windows theory. Their theory associates the trivial issues and dilemmas of a neighbourhood community or city with more serious concomitant dilemmas. For instance, shirk of POS management and maintenance (poor cleanliness and landscaping issues) may lead to more severe forms of overexploitation, such as free-riding, which contribute to be a 
safety and security issue in a neighbourhood. Whether they are self-interested, or opportunism triggered CPR POS dilemmas, they are both influenced by various environments that encompass them (Ostrom, 2005). Hence, in this paper, the environment described refers to the design of an institutional system (distribution and allocation of property rights structure and transaction costs), particularly concerning the impacts of property-rights failures on socialecological opportunistic behavioural interaction.

\subsection{An implication of property-rights failures on POS governance, efficiency and quality}

There are various property-rights system failures found in an SES which incentivise stakeholders to behave opportunistically and thus contribute to commons dilemmas and negative externalities (Ling et al., 2016, Ling and Leng, 2018). The issues cover security of rights (Grainger and Costello, 2011), conflict between de facto and de jure rights (Schlager and Ostrom, 1992), definition and clarity of rights (Coase, 1960), incompleteness of rights (Williamson, 1985), attenuation of rights (Furubotn and Pejovich, 1972) and suitability (mismatch) of alignment/allocation of rights (Webster and Lai, 2003); however, only the attenuation, incompleteness and maladaptiveness/misallocation of rights are discussed below (see more in Ling, 2017 on the security of rights of title deed and de facto rights emergence). Therefore, to identify whether a design of an institutional structure is adversarial or is associated with the above rights issues, Webster's evaluation approach (based on the outcome/performance of interaction: externalities from resources quality, sustainability, dissatisfaction and conflicts) (Webster and Lai, 2003; Webster, 2007) is suggested.

As Furubotn and Pejovich (1972) claim, attenuation of private rights is the restriction of exclusive private property (bundle) rights of an owner by the state's restrictive measures (via zoning and other contractual terms and conditions), where the diminution of rights can either be in the forms of freedom of utilisation, alienation, exclusivity, tenure duration and constructability on resources. It is also deemed a double-edged sword because weakening such rights may benefit a third party, e.g., for the enhancement of social-ecological wellbeing. Implicationally, property rights attenuation can be considered as "shrinkage of economic options" and "reduction in asset value" or "rent dissipation" (see Musole, 2009). Frech (1976) maintained that, the restriction of rights contributing to two kinds of opportunistic behaviours may result in resource overexploitation and resource management shirking. Since attenuated and weaker rights decrease the price/gain (value) of non-pecuniary amenities (e.g., POS), to compensate for the 'forfeited' benefits, individuals may be driven to overuse or maximise their use of the POS, thus reducing neighbourhood managerial efficiency and increasing management and maintenance costs. Whilst, as attenuated rights curtail the values and profits of the resources/POS (e.g., unable to own and transfer it, unable to develop it, unable to appropriate monetary income from it), management shirking by an individual may likely occur. In other words, since the owner's high investment or management costs in the lessvalue resource cannot even coincide with the low gains, thus, the most rational way for the owners is to shirk their management and maintenance duty (underinvestment). In short, adopting Webster and Lai's (2003) position, propertyrights attenuation does incentivise and encourage opportunistic private owners (developers/owners) to behave illegally, e.g., evading regulation, bribing/lobbying the government officials etc. for which other city dwellers bear negative externalities and social costs. This opportunistic act has been confirmed in Ling's (2017) study in that, aside from shirking of POS management duty, it is discovered that the private landowners (especially property developers) have misused a number of urban and neighbourhood POS by converting them for commercial use (e.g., petrol station and shopping malls) where they have higher profit and value.

For the incompleteness of property-rights, it is often treated interchangeably with ill-defined property-rights. Aside from Webster, who considers ill-definition of rights as public domain unallocated consumption rights (see Webster, 2002), well-defined property rights are also recognised and qualified when a property regime concerning control, ownership, management regime and rights is determined. Besides that, the restrictions, duties and rights associated with the resources must be generally identifiable, and when the resources are ultimately transferred or alienated to others, the duties and rights will be transferred together as well. However, well-defined rights need not inevitably entail complete rights (Ling et al., 2016) as all complex contracts (property-rights exchanges) are unavoidably incomplete (Williamson, 1975; see Demsetz, 1988), since transaction cost matters and is highly positive in 
the ex-ante rights assignation stage. Therefore, "an incomplete contract has gaps, missing provisions, and ambiguities and has to be completed (by renegotiation or by the courts)..." (Hart, 1995; see Shavell, 2004 for the illustration of the incompleteness of rights situation). Kim and Mahoney (2005) concur that in the incompleteness of rights (non-contractible rights), there will always be difficulties in identifying in advance all possible future contingencies. Similar to ill-definition of rights' negative consequences, incomplete rights pose non-contractible elements which hence increase the ex-post costs and perverse incentives (opportunistic behaviour). Once the rights enforcement is not vouched for, the property value diminishes because, by considering the unrecoverable loss about the rights violation by others, the expected income and utility of the asset are discounted. Therefore, such incomplete property rights (unspecified rights and duties of POS) are vulnerable to overexploitation, moral hazard, free-riding and management shirking (underinvestment) (Williamson, 2000; Ling, 2017). For example, the ambiguity of POS maintenance and management rights concerning 'how and when' results in some opportunistic managers and landowners mismanaging and underinvesting in POS. Overlapping management rights between landowners and local governments opens up the risk of moral hazards against the latter. Unclear use rights with respect to operational procedures and guidelines of POS facilities and amenities may also lead users to overexploitation (e.g., vandalism and cleanliness issues).

Another property rights tragedy is maladaptive rights, which generally occurs within a mismatched and unfeasible property-right regime. Such mal-assigned rights are synonymous with, or can be taken as, misallocation of resources. This previous situation is about the efficiency of the propertyrights, i.e., to what extent are the social-POS interaction and its outcome efficiently governed and managed under the current property-rights regime (see Webster and Lai, 2003). The resources (POS) should be allocated to those organisations and agents who are in the strongest and most suitable position to govern and manage the resource's contribution to the desired and efficient outcome. Generally, this can also cover other types of property-rights tragedies (e.g., incomplete right and attenuated right) above, as those rights tragedies may ultimately contribute to similar negative externalities as the misallocated rights.
However, it is worth noting that although the institutions are not severely attenuated nor have been fully well-defined and secured as per the descriptions above, it does not suffice to signify the adaptiveness and efficiency of a property regime in governing the resources (POS) management and utilisation. Various positive/high ex-post transaction costs, such as political influence, rent-seeking and lobbying behaviours, bureaucratic/administrative and financial budgetary issues, heavily centralised information, sole monopolisation, low precedence on non-pecuniary POS, overwhelming workload, technicalities and workforce constraints are still incurred and failed to be internalised under the state property regime. Therefore, due to high cooperation and negotiation costs in enforcing the management rights, inability, burdens, and perverse incentives are ensued to the rights holders, who may then likely act opportunistically towards POS management and consumption, e.g., freeride/overuse/misuse of POS and shirk the policing and management duties (Musole, 2009; see also Ling et al., 2016, Ling and Leng, 2018; Foster and Laione, 2016; Foster, 2011; Heltberg, 2002). See Ling (2017) for other possible elements, and how the inefficient maladaptive state property regime and the open-access resource system contribute to underinvestment, the Hardinian overuse tragedy, and different types of POS dilemmas.

Succinctly, the property-rights failures above are intricately interrelated to each other, and respectively contribute to their specific commons dilemmas and negative externalities. This scenario is consistent with Musole's (2009) position that negative externalities or dilemmas (e.g., shirking or overexploitation) will be worsened if those rights issues (e.g., incompleteness and attenuation as well as maladaptive rights) have co-occurred, which is typically discovered in one institution. Therefore, the prior institutional-socialecological system (property-rights tragedies predicaments and their market-POS dilemmas) requires a more holistic and adaptive countermeasure (i.e., re-alignment of institutions and property system is vital and imperative) (Webster, 2007). Finally, all in all, to recap the above review, a conceptual framework is established and illustrated as follows (Figure 2); this nexus showcases interconnections between the failures of institutional system (propertyrights issues, high transaction costs and perverse incentives distribution), and opportunistic social-ecological interaction, which leads to various social dilemmas and negative 
externalities and the need for institutional change

(re-alignment of rights).

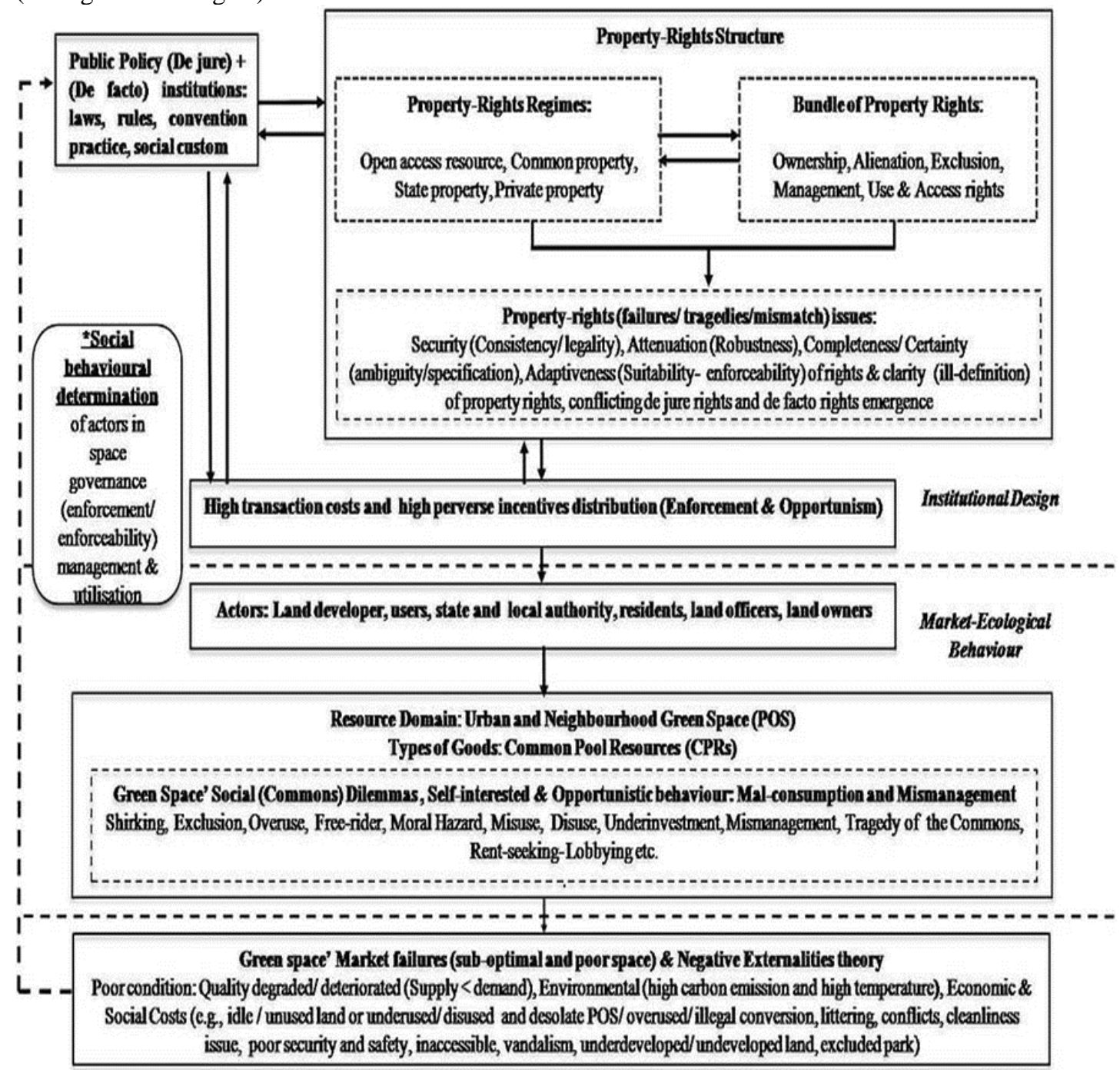

Sub-optimal Green Commons Outcome

Figure 2 - A Social-Ecological System Based Conceptual Framework

\section{CONCLUSION}

The SES-NIE based conceptual framework is crucial and relevant at explaining the status quo of urban and neighbourhood POS governance and sustainability issues, particularly through the understanding of the institutional property-rights and (perverse) transaction costs and incentives system distribution. The social-POS opportunistic behaviour and commons dilemmas are indeed incentivised and externalised when one institution is associated with the above numerous property-rights tragedies that ensue in high transaction costs and high perverse incentives. However, more empirical studies are required to confirm and improve this conceptual framework which is yet to be finalised and considered conclusive. Better still, exploration of other types of right issues and common dilemmas and their instances by future research are also appreciated, perhaps in different urban and neighbourhood commons settings. This narrative synthesis eventually suggests that reassignment of certain property right regimes (e.g., state property, open-access resource and private property) of POS to the commonproperty regime (see Ostrom, 1990 on the eight design principles) is necessary for the better public interest. Such a collective-action selfgoverning and organising model with a polycentricity attribute is believed to outperform the conventional centralised state regime, resulting in lower cooperation, monitoring, operational costs and perverse incentives, and thus disincentivising the opportunistic behaviour (less shirk and overuse) and commons dilemmas. 
Instead of state-owned CPR POS, this rights realignment mechanism provides community club goods. By virtue of its non-rivalrous and exclusionary properties, POS can be more efficient and sustainable; it is less contested and renders an opportunity for better control and commercialisation (membership fees), which incentivise better management (see Webster, 2007; Ling and Leng, 2018). This synthesis suggests policy and management insights to public officials, practitioners and consumers so that they are more aware of the importance of the institutional-social-ecological perspective in the POS context, and hence consider the reengineering of the POS ownership regime and management rights via the adaptive propertyrights structure re-allocation when necessary. Therefore, this study hopes to help devise efficient POS governance and management, which ultimately would contribute to creating a more sustainable society.

\section{ACKNOWLEDGEMENT}

This work was financially supported by the Ministry of Education Malaysia and Universiti Teknologi Malaysia through the Research University Grant (GUP) Q.J130000.2652.16J54.

\section{REFERENCES}

1 Adhikari, B. (2001). Literature review on the economics of common property resources: review of common pool resource management in Tanzania. Report Prepared for NRSP Project R7857. Centre for Ecology, Law and Policy, Environment Department, The University of York, York.

2 Boydell, S., and Searle, G. (2014). Understanding Property Rights in the Contemporary Urban Commons. Urban Policy and Research, 32(3), 323-340.

3 Brown, A. (2015). Claiming the Streets: Property Rights and Legal Empowerment in the Urban Informal Economy. World Development, 76, 238-248.

4 Buck, S. J. (1998). The global commons: an introduction. Washington, DC: Island Press.

5 Buitelaar, E., and Needham, B. (2007). Epilogue: Property rights between tools and social values. Town Planning Review, 78(1), 119-122.
6 Chen S. C. Y., and Webster, C. (2012). Institutional Economics: New. In S. J. Smith, M. Elsinga, L. F. O'Mahony, O. S. Eng, S. Wachter, K. Gibb (Eds.), International Encyclopaedia of Housing and Home, 4 (pp. 78-85). Oxford: Elsevier.

7 Ciriacy-Wantrup, S.V., and R. C. Bishop. (1975). - "Common property" as a concept in natural resources policy. Natural Resources Journal, 5(4), 713-727.

8 Coase, R. (1960). The Problem of Social Costs. Journal of Law and Economics, 3.

9 Colding, J., Barthel, S., Bendt, P., Snep, R., van der Knaap, W., and Ernstson, H. (2013). Urban green commons: Insights on urban common property systems. Global Environmental Change, 23(5), 1039-1051.

10 Demsetz, H. (1967). Towards a theory of property rights. American Economic Review, Papers and Proceedings, 57(2), 347-359.

11 Demsetz, H. (1988). A Framework for the Study of Ownership. Ownership, Control and the Firm, 12-27.

12 Eggertsson, T. (1990). The role of transaction costs and property rights in economic analysis. European Economic Review, 34, 450-457.

13 Foster, S. R. (2011). Collective Action and the Urban Commons. Notre Dame Law Review, 87, 57-134.

14 Foster, S., and Laione, C. (2016). The city as a commons. Yale Law Policy Review, 34(2), 1-69.

15 Frech, H. E. (1976). The Property Rights Theory of the Firm: Empirical Results from a Natural Experiment. Journal of Political Economy, 84, February, 143-152.

16 Furubotn, E. G., and Pejovich, S. (1972). Property rights and economic theory: A survey of recent literature. Journal of Economic Literature, 10(4), 1137-1162.

17 Gerber, J.-D., Knoepfel, P., Nahrath, S., and Varone, F. (2009). Institutional Resource Regimes: Towards sustainability through the combination of property rights theory and policy analysis. Ecological Economics, 68(3), 798-809. 
18 Grafton, R. Q. (2000). Governance of the commons: a role for the state? Land Economics, 76, 504-517.

19 Grainger, C. A., and Costello, C. (2011). The value of secure property rights: Evidence from global fisheries. National Bureau of Economic Research Working Paper Series.

20 Hanna, S. S., Folke, C., and Maler, K. G. (1996). Rights to Nature: Ecological, Economic, Cultural and Political Principles of Institutions for the Environment. Washington, DC: Island Press.

21 Hardin, G. (1968). The tragedy of the commons. Science, 162, 1243-1248.

22 Hart, O. (1995). Firms, Contracts, and Financial Structure. Oxford: Oxford University Press.

23 Heltberg, R. (2002). Property rights and natural resource management in developing countries. Journal of Economic Surveys, 16(2), 189- 214.

24 Hess, C. (2008). Mapping the New Commons. Paper presented at the 12th Biennial Conference of the International Association for the Study of the Commons, University of Gloucestershire, Cheltenham, 14-18 July. Retrieved October 10, 2014 from

http://dlc.dlib.indiana.edu/dlc/handle/10535 1304 .

25 Khachatryan, H., Joireman, J., and Casavant, K. (2013). Relating values and consideration of future and immediate consequences to consumer preference for biofuels: A three-dimensional social dilemma analysis. Journal of Environmental Psychology, 34, 97-108.

26 Kherallah, M., and Kirsten, J. F. (2002). The new institutional economics: Applications for agricultural policy research in developing countries. Agrekon, 41(2), 111133.

27 Kim, J., and Mahoney, J. T. (2005). Property rights theory, transaction costs theory, and agency theory: An organizational economics approach to strategic management. Managerial and Decision Economics, 26, 223-242.
28 Lai, L. W. C. (2014). As planning is everything, it is good for something! A coasian economic taxonomy of modes of planning. Planning Theory, 15(3), 255-273.

29 Lai, L. W. C., Davies, N. G. S., and Lorne, F. (2015). Creation of property rights in planning by contract and edict: Beyond "Coasian bargaining" in private planning. Planning Theory, 9, 1-17.

30 Lee, S., and Webster, C. (2006). Enclosure of the urban commons. GeoJournal, 66(12), 27-42.

31 Libecap, G. D. (1991). Contracting for property rights. Cambridge, UK: Cambridge University Press.

32 Ling G. H. T., Chau L. W., Ho C. S., Ali H. M. (2018). Low-Carbon Ability of Neighbourhood Public Open Space (POS) Governance: Explanation from SocialEcological System and New Institutional Economics, Chemical Engineering Transactions 63, 469-474.

33 Ling, G. H. T. (2017). Institutional Property Rights of Residential Public Open Space In Sabah, Malaysia. PhD Thesis. Faculty of Built Environment and Surveying, Universiti Teknologi Malaysia.

34 Ling, G. H. T., \& Leng, P. C. (2018). Ten Steps Qualitative Modelling: Development and Validation of Conceptual InstitutionalSocial-Ecological Model of Public Open Space (POS) Governance and Quality, Resources 7(4), 62.

35 Ling, G. H. T., Ho, C. S., Ali, H. M., and Tu. F. (2016). Do institutions matter in neighbourhood commons governance? A two-stage relationship between diverse property-rights structure and residential public open space (POS) quality: Kota Kinabalu and Penampang, Sabah, Malaysia. International Journal of the Commons, 10(1), 294-333.

36 Ling, G. H. T., Ho, C. S., and Ali, H. M. (2014). Ostrom's Design Principles in Residential Public Open Space Governance: Conceptual Framework and Literature Review Contemporary Urban Commons Resources, POS. International Journal of Built Environment and Sustainability, 1(1), 27-37. 
37 Ling, G. H. T., Ho, C. S., Tsau, K. Y., \& Cheng, C. T. (2019). Interrelationships between Public Open Space, Common Pool Resources, Publicness Levels and Commons Dilemmas: A Different Perspective in Urban Planning. International Journal of Built Environment and Sustainability, 6(2), 1321.

38 Malek, N. A., Mohammad, S. Z., \& Nashar, A. (2018). Determinant Factor for Quality Green Open Space Assessment in Malaysia. Journal of Design and Built Environment, 18(2), 26-36.

39 McCarter, M. W., Samek, A. C., and Sheremeta, R. M. (2014). Divided loyalists or conditional cooperators? Creating consensus about cooperation in multiple simultaneous social dilemmas. Group and Organisation Management, 39(6),744-771.

40 Musole, M. (2009). Property rights, transaction costs and institutional change: Conceptual framework and literature review. Progress in Planning, 71(2), 43-85.

41 North, D. C. (1990). Institutions, institutional change and economic performance.Cambridge and New York: Cambridge University Press.

42 Ostrom, E. (1990). Governing the Commons: The Evolution of Institutions for Collective Action. New York, NY: Cambridge University Press.

43 Ostrom, E. (2002). Type of goods and collective action. Presented at Public Choice Society Annual Meeting, San Diego, CA (March).

44 Ostrom, E. (2005). Understanding Institutional Diversity. Princeton, NJ: Princeton University Press.

45 Ostrom, E. (2009). A general framework for analyzing sustainability of social ecological systems. Science, 325(5939), 419-422.

46 Pigou, A. C. (1932). The economics of welfare. London: Macmillan.

47 Rapoport, A. (1998). Decision theory and decision behaviour. UK: Palgrave Macmillan.
48 Sangmoo, K. (2015). Public spaces-not a 'nice to have' but a basic need for cities'. End Poverty in South Asia. Retrieved June 10, 2015 from http://blogs.worldbank.org/endpovertyinso uthasia/publicspaces-not-nice-have-basicneed-cities.

49 Schlager, E., and Ostrom, E. (1992). Property-Rights Regimes and Natural Resources: A Conceptual Analysis. Land Economics, 68(3), 249-262.

50 Shavell, S. (2004). Foundations of Economic Analysis of Law. Cambridge, Mass: Belknap Press of Harvard University Press.

51 Smith, A. (1776). An inquiry into the nature and causes of the wealth of nations, 1976 edition. Chicago, IL: University of Chicago.

52 Soo, C. Y.Y., Norhayati, M and Norafida, A.G. (2018). An Overview of Influencing Factors of Thermal Performance for Open Spaces in the Tropics. Journal of Design and Built Environment, 18(2), 1-14.

53 The Ronald Coase Institute. (n.d.). Glossary for New Institutional Economics. Retrieved from https://www.coase.org/nieglossary.htm.

54 Tiebout, C. M. (1956). A pure theory of local expenditures. Journal of Political Economy, 5, 416-424.

55 Webster, C. (2002). Property rights and the public realm: gates, green belts, and Gemeinschaft. Environment and Planning B: Planning and Design, 29(3), 397-412.

56 Webster, C. (2007). Property rights, public space and urban design. Town Planning Review, 78(1), 81-101.

57 Webster, C. J., and Lai, L. W. C. (2003). Property rights, planning and markets: Managing spontaneous cities. Cheltenham, UK; Northampton, MA: Edward Elgar.

58 Williamson, O. E. (1975). Markets and hierarchies. New York: Free Press.

59 Williamson, O. E. (1985). The economic institutions of capitalism. New York: Free Press. 
60 Williamson, O. E. (2000). The new institutional economics: Taking stock, looking ahead. Journal of Economic Literature, 38(3), 595- 613.

61 Wilson, J. Q., and Kelling, G. L. (1982). Broken Windows: The Police and Neighbourhood Safety. Atlantic Monthly, 249(3), 29-38 